\title{
Influence of genetic susceptibility on the urinary excretion of 8-hydroxydeoxyguanosine of firefighters
}

Yun-Chul Hong, Hye-Sook Park, Eun-Hee Ha

\begin{abstract}
Objectives-Oxidative DNA damage has been implicated in carcinogenesis. The DNA damage can be assessed from the urinary excretion of the DNA-repair product 8-hydroxydeoxyguanosine (8$\mathrm{OH}-\mathrm{dG})$. The factors were investigated that influenced the excretion of urinary 8-OH-dG in 78 firefighters.

Methods-53 Out of 78 firefighters were exposed to fire within 5 days of the study and 25 were not. 8-OH-dG was measured by ELISA and the distribution of the genotypes of CYP1A1, CYP2E1, GSTM1, and GSTT1 was measured by polymerase chain reaction.

Results-The homozygous wild type frequencies of CYP1A1 MspI, CYP1A1 ileval, CYP2E1, GSTM1, and GSTT1 were $31.5 \%, 56.2 \%, 60.3 \%, 50.7 \%$, and $53.4 \%$, respectively. The geometric mean of urinary $8-\mathrm{OH}-\mathrm{dG}$ was $14.1 \mathrm{ng} / \mathrm{mg}$ creatinine in more active firefighters and $12.3 \mathrm{ng} / \mathrm{mg}$ creatinine in non-exposed and less active subjects. Significantly increased concentrations of urinary 8-OH-dG were found to be associated with cigarette smoking, and $14 \%$ of the variation of $8-\mathrm{OH}-\mathrm{dG}$ was explained by cigarettes smoked per day. The CYP1A1 MspI, CYP1A1 ile-val, GSTM1, and GSTT1 genetic polymorphisms were not found to be significantly associated with the urinary excretion of 8-OH-dG. However, the subjects carrying the CYP2E1 mutant type excreted higher concentrations of $8-\mathrm{OH}-\mathrm{dG}$ and there was a marginally significant interaction of GSTT1 with firefighting activity. Multiple regression analysis confirmed that smoking was the strongest predictor of excretion of 8-OH-dG. Age, body mass index, and firefighting activity were not significant predictive factors for urinary $8-\mathrm{OH}-$ dG.

Conclusion-Smoking and CYP2E1 gene polymorphism may be important factors in carcinogenesis and the GSTT1 positive genotype may be a genetic susceptibility factor in firefighters who are exposed regularly to various chemical carcinogens. (Occup Environ Med 2000;57:370-375)
\end{abstract}

Keywords: firefighters; 8-hydroxydeoxyguanosine; susceptibility

Firefighters are often exposed to carcinogens. ${ }^{1}$ The commonly encountered ones in firefight- ing include asbestos, arsenic, benzene, benzo(a)pyrene and other polycyclic aromatic hydrocarbons (PAHs), cadmium, chlorophenols, chromium, diesel fumes, dioxins, ethylene oxide, formaldehyde, $o$-toluidine, polychlorinated biphenyls, and vinyl chloride. ${ }^{2}$ As a result of the recent proliferation of synthetic substances, firefighters are increasingly exposed to new hazards and often exposed to multiple hazards simultaneously. ${ }^{2}$ With respiratory protection offering uncertain efficacy and limited acceptability in workplaces ${ }^{3}$ and firefighters being exposed to intermittent and variable amounts of carcinogens, the importance of such exposure is still unresolved. Thus, the purpose of this study was to investigate the effect of exposure to different carcinogenic agents among firefighters on the urinary excretion of 8-hydroxydeoxyguanosine $(8-\mathrm{OH}-$ $\mathrm{dG}$ ) and to assess whether the polymorphism of metabolic enzymes influence this urinary biomarker.

Epidemiological studies strongly suggest that firefighters are at an increased risk of developing and dying from leukaemia, ${ }^{45}$ nonHodgkin's lymphoma, ${ }^{56}$ multiple myeloma, ${ }^{78}$ and cancers of the brain and bladder. ${ }^{69}$ Genetic polymorphisms in the enzymes that metabolise xenobiotics have been associated with differences in risk of cancer. The PAHs are abundant in fire and are thought to be responsible for an increased risk of cancer in firefighters. The phase I enzymes represented by the cytochrome $P-450$ enzymes oxidise PAHs into DNA binding diolepoxide metabolites, which are detoxified by the phase II enzymes, including the glutathione S-transferase superfamily. It is, therefore, possible that individual variations in metabolic activities in each phase regulate the generation of reactive oxygen species, and thus are partially responsible for individual susceptibility to cancers related to PAHs.

One of the oxidative DNA products, 8-OH$\mathrm{dG}$, is physiologically formed and enhanced by chemical carcinogens. ${ }^{10}$ Damaged DNA is repaired in vivo by exonucleases, and the resulting $8-\mathrm{OH}-\mathrm{dG}$ is excreted without further metabolism into urine. Thus, the urinary excretion of the hydroxylated nucleoside will reflect the current oxidative DNA damage and repair. ${ }^{11}$

We studied the distribution of the genotypes of CYP1A1, CYP2E1, GSTM1, and GSTT1 in firefighters and assessed how the urinary excretion of $8-\mathrm{OH}-\mathrm{dG}$ is modified by the genetic polymorphisms. Because of the potential confounding effects of smoking, our study 
Table 1 Descriptive data of 73 firefighters classified by their activity and their distribution according to genetic subtypes

\begin{tabular}{|c|c|c|c|}
\hline & $\begin{array}{l}\text { No active duty } \\
\text { (not exposed to fire } \\
\text { in } 5 \text { days) }\end{array}$ & $\begin{array}{l}\text { Less active duty } \\
\text { (exposed to fire }<8 \mathrm{~h} \text { in } \\
5 \text { days) }\end{array}$ & $\begin{array}{l}\text { More active duty } \\
\text { (exposed to fire } \geqslant 8 \mathrm{~h} \\
\text { in } 5 \text { days) }\end{array}$ \\
\hline Subjects (n) & 24 & 36 & 13 \\
\hline Age (mean (SD)) & $36.0(8.2)$ & $33.0(5.7)$ & $35.0(7.6)$ \\
\hline Cigarettes/day (mean (SD)) & $20.0(6.6)$ & $19.3(9.5)$ & $25.0(9.2)$ \\
\hline \multicolumn{4}{|l|}{ CYP1A1M: } \\
\hline $\mathrm{m} 1 / \mathrm{m} 1$ & 8 & 13 & 2 \\
\hline $\mathrm{m} 1 / \mathrm{m} 2, \mathrm{~m} 2 / \mathrm{m} 2$ & 16 & 23 & 11 \\
\hline \multicolumn{4}{|l|}{ CYP1A1I: } \\
\hline $\mathrm{I} / \mathrm{I}$ & 14 & 21 & 6 \\
\hline $\mathrm{I} / \mathrm{V}, \mathrm{V} / \mathrm{V}$ & 10 & 15 & 7 \\
\hline \multicolumn{4}{|l|}{ CYP2E1: } \\
\hline $\mathrm{c} 1 / \mathrm{c} 1$ & 16 & 22 & 6 \\
\hline $\mathrm{c} 1 / \mathrm{c} 2, \mathrm{c} 2 / \mathrm{c} 2$ & 8 & 14 & 7 \\
\hline \multicolumn{4}{|l|}{ GSTM1: } \\
\hline+ & 13 & 19 & 5 \\
\hline - & 11 & 17 & 8 \\
\hline \multicolumn{4}{|l|}{ GSTT1: } \\
\hline+ & 13 & 17 & 9 \\
\hline - & 11 & 19 & 4 \\
\hline
\end{tabular}

shows effects of smoking separately from firefighting activities.

\section{Subjects and methods}

The subjects were 78 firefighters from a fire department in Inchon, Korea. They were volunteers from the 96 firefighters of the department who were invited to participate. Fifty three firefighters were exposed to fire within 5 days of the study and 25 were not. The firefighters, aged $21-58$ years, were asked to collect spot urine samples in the morning before breakfast. The urine samples were frozen and kept in the dark until analysis. Physical examination and blood collection were done at the same time. They were asked to complete questionnaires, which included questions on current smoking habit and the previous day's diet. The diet questions were focused on the consumption of grilled meat or fish. Information on firefighting activity (hours spent in firefighting) was obtained from the activity $\log$ of the department. Four subjects were excluded from the study because their blood and urine samples proved to be inadequate. We also excluded female data from the analysis because only one woman participated. The characteristics of the study population are presented in table 1 .

URINARY 8-OH-DG

The amount of urinary 8-OH-dG was measured with an ELISA kit (Japan Institute for the Control of Aging). This was a competitive in vitro ELISA for measurement of the oxidative DNA adduct $8-\mathrm{OH}-\mathrm{dG}$ in urine. Urine samples were thawed and centrifuged to remove particulate matters. Fifty microlitres of primary monoclonal antibody and $50 \mu \mathrm{l}$ of sample or standard were added to microtitre plates, which were precoated with $8-\mathrm{OH}-\mathrm{dG}$. The plates were sealed tightly and incubated at $37^{\circ} \mathrm{C}$ for 1 hour, followed by a wash with $250 \mu \mathrm{l}$ phosphate buffered saline (PBS). One hundred microlitres of secondary antibody conjugated to horse radish peroxidase was then added to each well, incubated, and washed. One hundred microlitres of enzyme substrate was then added to each well, and the reaction ended by addition of $100 \mu \mathrm{l} 1 \mathrm{~N}$ phosphoric acid.
Absorbance readings were taken 3 minutes later with a spectrophotometer at $450 \mathrm{~nm}$. The amount of $8-\mathrm{OH}-\mathrm{dG}$ in each subject was calculated by comparison with a standard curve.

GENOTYPING

The genetic polymorphism was analysed with polymerase chain reaction (PCR) amplification in a Techne progene thermal cycler. All PCR reactions were carried out in a total volume of $50 \mu \mathrm{l}$ in the presence of $10 \mathrm{mM}$ Tris-HCl, $\mathrm{pH}$ $8.3 ; 50 \mathrm{mM} \mathrm{KCl} ; 0.2 \mathrm{mM}$ of each dNTP; 2.0 $\mathrm{mM} \mathrm{MgCl} ; 1.25$ units Taq polymerase; 20 pmol of each primer; and $100 \mathrm{ng}$ genomic DNA as template.

The GSTM1 and GSTT1 gene deletions were analysed simultaneously. Primers used to detect the GSTM1 deletion were as follows: 5' - GAACTCCCTGAAAAGCTAAAGC - 3' and 5'-GTTGGGCTCAAATATACGGTGG -3 '. Primers used to detect the GSTT1 deletion were as follows: 5'-TTCCTTACT GGTCCTCACATCTC-3' and 5'-TCACCG GATCATGGCCAGCA-3'. A 268 bp (base pair) fragment of the $\beta$-globin gene was coamplified as an internal positive control with the following primers: 5'-CAACTTCATCCA CGTTCACC-3' and 5'-GAAGAGCCAAGG ACAGGTAC-3'. After an initial denaturation at $94^{\circ} \mathrm{C}$ for 5 minutes, 35 cycles were run with denaturation at $94^{\circ} \mathrm{C}$ for 1 minute, annealing at $65^{\circ} \mathrm{C}$ for 1 minute and extension at $72^{\circ} \mathrm{C}$ for 1 minute. The PCR products were electrophoresed on a $4 \%$ NuSieve 3:1 agarose gel. Gels were stained in aqueous solutions of ethidium bromide $(0.5 \mu \mathrm{g} / \mathrm{ml})$ and were photographed with a polaroid camera under UV light. Amplified $215 \mathrm{bp}$ and $480 \mathrm{bp}$ products indicated the presence of the GSTM1 and GSTT1 genes, respectively.

Two separate point mutation polymorphisms of the CYP1A1 gene were analysed in each subject with the PCR restriction enzyme digest genotyping method.

The CYP1A1 genotypes ascribed to the presence $(\mathrm{m} 2)$ or absence $(\mathrm{m} 1)$ of the $M s p \mathrm{I}$ site at the 264th base from the polyadenylate

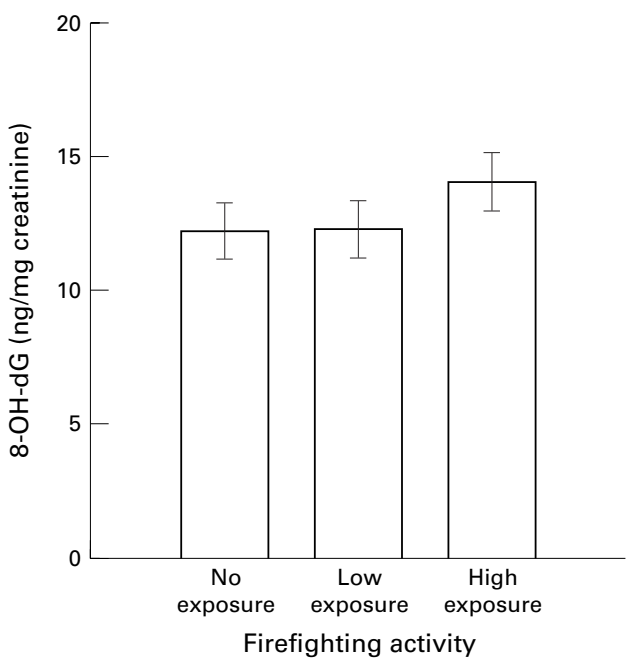

Figure 1 Urinary concentrations of 8-OH-dG $(\mathrm{ng} / \mathrm{mg}$ creatinine) classified by firefighting activity. 


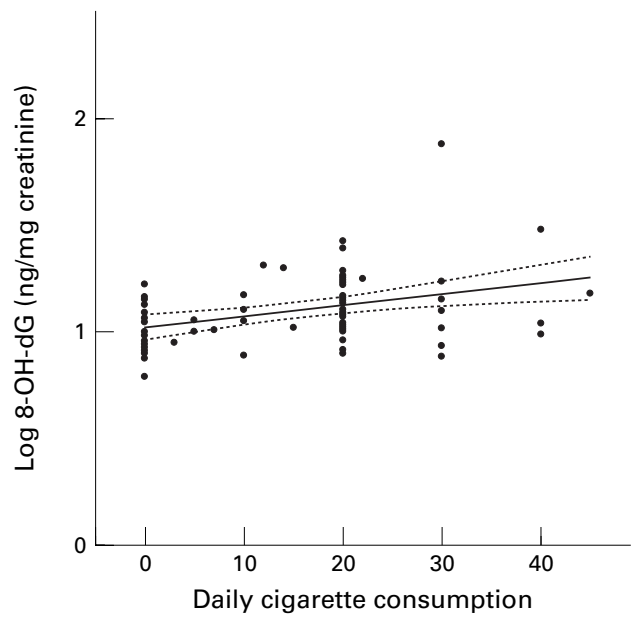

Figure 2 Relation between urinary concentration of 8-OH-dG and number of cigarettes smoked per day (regression line: $\log$ (urinary $8-O H-d G)=0.005 \times$ number of cigarettes/day $+1.023(p=0.001)$, upper and lower lines show $95 \%$ CIs).

additional signal in the 3'-flanking region were identified with PCR and restriction enzyme digestion. Primers used in the MspI PCR amplification were 5'-CAGTGAAGAGGT GTAGCCGCT-3' and 5'-TAGGAGTCT TGTCTCATGCCT-3'. After an initial denaturation at $94^{\circ} \mathrm{C}$ for 4 minutes, amplifications were performed with 35 cycles of denaturation at $94^{\circ} \mathrm{C}$ for 1 minute, annealing at $62^{\circ} \mathrm{C}$ for 1 minute, and extension at $72^{\circ} \mathrm{C}$ for 1 minute. The enzyme $M s p$ I (2.5 units) was added to 10 $\mu l$ of the PCR amplified reaction mixture, and the resulting mixture was incubated for 3 hours at $37^{\circ} \mathrm{C}$. Restriction fragments were analysed by electrophoresis on a $1.8 \%$ agarose gel. The genotype $\mathrm{m} 1 / \mathrm{m} 1$ formed an uncleaved $340 \mathrm{bp}$ band, whereas genotype $\mathrm{m} 2 / \mathrm{m} 2$ generated two bands, of 200 and 140 bp. The heterozygous genotype corresponded to three bands, of 340, 200, and $140 \mathrm{bp}$ long.

The presence of the CYP1A1 exon 7 mutation, which codes for valine (val) rather than isoleucine (ile), was determined with PCR and restriction enzyme digestion. Primers used to detect the ile-val polymorphism were as follows: 5'-GAACTGCCACTTCAGCTG TCT-3' and 5'-CCAGGAAGAGAAAGACC TCCCAGCGGGCCA-3'. After an initial denaturation at $94^{\circ} \mathrm{C}$ for 5 minutes, 35 cycles were run with denaturation at $94^{\circ} \mathrm{C}$ for 1

Table 2 Geometric mean (SE) concentrations of urinary 8-OH-dG (ng/mg creatinine) in firefighters by genetic subtypes

\begin{tabular}{lllll}
\hline & $\begin{array}{l}\text { Subjects } \\
(n)\end{array}$ & $\begin{array}{l}\text { No active duty } \\
(n=24)\end{array}$ & $\begin{array}{l}\text { Less active duty } \\
(n=36)\end{array}$ & $\begin{array}{l}\text { More active duty } \\
(n=13)\end{array}$ \\
\hline $\begin{array}{l}\text { CYP1A1 MspI: } \\
\text { m1/m1 }\end{array}$ & 23 & $13.2(1.1)$ & $13.1(1.2)$ & $14.3(1.3)$ \\
$\begin{array}{l}\text { m1/m2,m2/m2 } \\
\text { CYP1A1 ile-val: }\end{array}$ & 50 & $11.8(1.1)$ & $11.9(1.1)$ & $14.1(1.1)$ \\
$\quad \begin{array}{ll}\text { ile/ile } \\
\text { ile/val, val/val }\end{array}$ & 41 & $12.5(1.1)$ & $13.1(1.1)$ & $16.0(1.2)$ \\
$\begin{array}{l}\text { CYP2E1: } \\
\quad \text { c1/c1 }\end{array}$ & 32 & $11.9(1.1)$ & $11.4(1.1)$ & $12.7(1.1)$ \\
$\quad$ c1/c2,c2/c2 & 44 & $11.5(1.1)$ & $11.7(1.1)$ & $13.6(1.1)$ \\
$\begin{array}{l}\text { GSTM1: } \\
\quad+\end{array}$ & 29 & $13.9(1.1)$ & $13.4(1.2)$ & $14.6(1.1)$ \\
$\quad-\quad$ & 37 & $12.5(1.1)$ & $12.4(1.1)$ & $13.6(1.1)$ \\
GSTT1: & 36 & $12.0(1.1)$ & $12.2(1.2)$ & $14.4(1.1)$ \\
$\quad+$ & 39 & $12.2(1.1)$ & $12.2(1.1)$ & $15.1(1.1)$ \\
- & 34 & $12.4(1.1)$ & $12.4(1.1)$ & $12.2(1.1)$ \\
\hline
\end{tabular}

minute followed by annealing extension at $68^{\circ} \mathrm{C}$ for 1 minute. The enzyme $N c o$ I $(2.5$ units) was added to $10 \mu \mathrm{l}$ of the PCR amplified reaction mixture, and the mixture was incubated for 3 hours at $37^{\circ} \mathrm{C}$. Restriction fragments were analysed by electrophoresis on a $1.8 \%$ agarose gel. The genotype ile/ile generated two bands, of 163 and $32 \mathrm{bp}$, whereas genotype val/val formed an uncleaved $195 \mathrm{bp}$ band. The heterozygous genotype corresponded to three bands, of 195,163 , and $32 \mathrm{bp}$ long.

The identification of the CYP2E1 genotypes ascribed to the presence (c2) or absence (c1) of the PstI site in the transcription regulation region was carried out with the PCR restriction enzyme digest genotyping method. The following primers were used in PCR reactions to amplify a $410 \mathrm{bp}$ fragment of the CYP2E1 gene containing a Pst $\mathrm{I}$ restriction site: 5'CCAGTCGAGTCTACATTGTCA-3' and 5'TTCATTCTGTCTTCTAACTGG-3'. After an initial denaturation at $94^{\circ} \mathrm{C}$ for 4 minutes, amplifications were performed with 35 cycles of denaturation at $94^{\circ} \mathrm{C}$ for 1 minute, annealing at $58^{\circ} \mathrm{C}$ for 1 minute and extension at $72^{\circ} \mathrm{C}$ for 1 minute. The enzyme PstI (5.0 units) was added to $10 \mu \mathrm{l}$ of the PCR amplified reaction mixture, and the mixture was incubated for 3 hours at $37^{\circ} \mathrm{C}$. Restriction fragments were analysed by electrophoresis on a $1.8 \%$ agarose gel. The genotype $\mathrm{c} 1 / \mathrm{c} 1$ formed an uncleaved 410 bp band, whereas genotype c2/c2 generated two bands, of 290 and $120 \mathrm{bp}$. The heterozygous genotype corresponded to three bands, of 410,290 , and $120 \mathrm{bp}$ long.

\section{STATISTICAL ANALYSIS}

Urinary concentrations of 8-OH-dG were log transformed to meet normality assumptions. Geometric mean values and geometric SEs were described as measures of the data distribution. Univariate statistical analyses were based on the $t$ test and analysis of variance (ANOVA). Simple regression analysis was used to investigate the relations between continuous variables and the log transformed concentrations of urinary $8-\mathrm{OH}-\mathrm{dG}$. Multiple regression analysis was performed to investigate the relative effects of covariates on the log transformed urinary concentration of $8-\mathrm{OH}-\mathrm{dG}$. Continuous explanatory covariates were

Table 3 Geometric mean (SE) concentrations of urinary 8-OH-dG (ng/mg creatinine) of non-smokers and smokers by genetic subtypes

\begin{tabular}{|c|c|c|c|}
\hline & $\begin{array}{l}\text { Subjects } \\
(n)\end{array}$ & $\begin{array}{l}\text { Non-smokers } \\
(n=21)\end{array}$ & $\begin{array}{l}\text { Smokers } \\
(n=52)\end{array}$ \\
\hline \multicolumn{4}{|l|}{ CYP1A1 MspI: } \\
\hline $\mathrm{m} 1 / \mathrm{m} 1$ & 23 & $11.4(1.1)$ & $13.9(1.1)$ \\
\hline $\mathrm{m} 1 / \mathrm{m} 2, \mathrm{~m} 2 / \mathrm{m} 2$ & 50 & $9.9(1.1)$ & $13.6(1.1)$ \\
\hline \multicolumn{4}{|l|}{ CYP1A1 ile-val: } \\
\hline ile/ile & 41 & $10.7(1.1)$ & $14.0(1.1)$ \\
\hline ile/val, val/val & 32 & $10.1(1.1)$ & $13.2(1.1)$ \\
\hline \multicolumn{4}{|l|}{ CYP2E1: } \\
\hline $\mathrm{c} 1 / \mathrm{c} 1$ & 44 & $9.9(1.1)$ & $13.0(1.1)$ \\
\hline $\mathrm{c} 1 / \mathrm{c} 2, \mathrm{c} 2 / \mathrm{c} 2$ & 29 & $11.2(1.1)$ & $14.7(1.1)$ \\
\hline \multicolumn{4}{|l|}{ GSTM1: } \\
\hline+ & 37 & $11.0(1.1)$ & $13.6(1.1)$ \\
\hline- & 36 & $9.2(1.1)$ & $13.8(1.1)$ \\
\hline \multicolumn{4}{|l|}{ GSTT1: } \\
\hline+ & 39 & $10.9(1.1)$ & $13.6(1.1)$ \\
\hline - & 34 & $9.6(1.1)$ & $13.8(1.1)$ \\
\hline
\end{tabular}


Table 4 Multiple regression analysis of the relation between urinary concentrations of $8-O H-d G$ and selected covariates

\begin{tabular}{|c|c|c|c|}
\hline Covariate & $\begin{array}{l}\text { Median } \\
\text { ratio }\end{array}$ & $95 \% C I$ & p Value \\
\hline \multicolumn{4}{|l|}{ Age (y): } \\
\hline$\leqslant 30$ & 1.000 & & \\
\hline $30-40$ & 0.958 & 0.795 to 1.155 & 0.657 \\
\hline$>40$ & 0.905 & 0.696 to 1.177 & 0.456 \\
\hline \multicolumn{4}{|c|}{ Body mass index $\left(\mathrm{kg} / \mathrm{m}^{2}\right)$ : } \\
\hline$\leqslant 20$ & 1.000 & & \\
\hline $20-25$ & 1.031 & 0.802 to 1.324 & 0.814 \\
\hline$>25$ & 0.961 & 0.716 to 1.291 & 0.794 \\
\hline \multicolumn{4}{|c|}{ Smoking (cigarettes/day): } \\
\hline Non-smoker & 1.000 & & \\
\hline$\leqslant 20$ & 1.269 & 1.044 to 1.543 & 0.017 \\
\hline$>20$ & 1.484 & 1.135 to 1.940 & 0.004 \\
\hline \multicolumn{4}{|l|}{ Firefighting: } \\
\hline Unexposed & 1.000 & & \\
\hline Less active duty & 0.969 & 0.807 to 1.164 & 0.740 \\
\hline More active duty & 1.067 & 0.833 to 1.367 & 0.609 \\
\hline \multicolumn{4}{|l|}{ CYP2E1: } \\
\hline $\mathrm{c} 1 / \mathrm{c} 1$ & 1.000 & & \\
\hline $\mathrm{c} 1 / \mathrm{c} 2, \mathrm{c} 2 / \mathrm{c} 2$ & 1.130 & 0.950 to 1.344 & 0.167 \\
\hline
\end{tabular}

categorised and dummy variables were created to represent the contrast between the reference and the other values. The exponentiation of the estimated regression coefficients gave rise to the median ratio. The median ratio was the ratio of the expected median value of the response variable for a given level of a given explanatory covariate to the expected median value in the reference level of that covariate. The confounding effect of other covariates was adjusted in the regression model. The statistical analyses were performed with the SAS (version 6.12) statistical package.

\section{Results}

Age distribution, smoking habits, and the frequency distributions for CYP1A1, CYP2E1, GSTM1, and GSTT1 genetic polymorphisms among the study subjects are reported in table 1 . The exposed subjects were divided into two groups; the first group comprised those who were exposed to fire $<8$ hours for the 5 days before the study (less active duty), and the second group comprised those who were exposed to fire $\geqslant 8$ hours (more active duty). The mean ages were 36.0 years in the reference group and 33.0 and 35.0 years in the two exposed groups, respectively. The mean number of cigarettes smoked a day was highest in the more active group (25.0 (9.2) cigarettes a day). The homozygous wildtype frequencies of CYP1A1 MspI, CYP1A1 ile-val, CYP2E1, GSTM1, and GSTT1 were $31.5 \%$, $56.2 \%, 60.3 \%, 50.7 \%$, and $53.4 \%$, respectively. The homozygous and heterozygous allelic variants were combined in the statistical analysis. The geometric mean concentrations of urinary 8-OH-dG were highest in more active firefighters $(14.1 \mathrm{ng} / \mathrm{mg}$ creatinine). The mean concentrations were not different between non-exposed and less active firefighters

Table 5 Changes in the estimated median ratios (95\% CIs) of firefighting activity for urinary 8-OH-dG concentrations according to GSTT1 polymorphism

\begin{tabular}{lll}
\hline Firefighting activity & GSTT1 positive & GSTT1 null \\
\hline Unexposed & 1.000 & 1.000 \\
Less active duty & $1.008(0.933$ to 1.089$)$ & $0.976(0.848$ to 1.123$)$ \\
More active duty & $1.054(0.961$ to 1.158$)$ & $0.916(0.732$ to 1.146$)$ \\
\hline
\end{tabular}

(12.3 ng/mg creatinine). The concentrations of urinary 8-OH-dG from non-exposed and exposed subjects are shown in figure 1 . The ANOVA performed on log transformed data showed that urinary $8-\mathrm{OH}-\mathrm{dG}$ in the more active firefighters was not significantly higher than in other subjects $(p=0.51)$. Moreover, confounding factors such as smoking and CYP2E1 did not influence this significance. Significantly increased concentrations of urinary $8-\mathrm{OH}-\mathrm{dG}$ were attributed to cigarette smoking $(p=0.001)$, and this significance was unchanged after the removal of the obvious outlier $(p=0.002$, fig 2$)$. The proportion of variation of $8-\mathrm{OH}-\mathrm{dG}$ explained by cigarettes smoked per day was $14 \%$. The ANOVA showed that diet and alcohol consumption were not significantly related to the concentration of urinary $8-\mathrm{OH}-\mathrm{dG}$.

The CYP2E1 genetic polymorphism was found by ANOVA to be marginally significantly associated with the urinary excretion of $8-\mathrm{OH}-\mathrm{dG}$ by firefighters $(\mathrm{p}=0.10)$. When the subjects were stratified by firefighting activities and smoking habits (table 2 and 3), these effects did not change among the subgroups. However, there was no relation for the interaction of CYP2E1 and firefighting or smoking $(p=0.61)$. Although firefighters carrying the CYP1A1 MspI and CYP1A1 ile-val wildtype exhibited higher concentrations of excreted 8-OH-dG, these genotypes were not significantly related to the excretion of $8-\mathrm{OH}-\mathrm{dG}$. The GSTM1 and GSTT1 polymorphisms showed no correlation with concentrations of 8-OH-dG. However, there was a marginally significant interaction between GSTT1 polymorphism and firefighting activity by multivariate analysis $(p=0.06)$.

Multiple regression analysis involving age, body mass index, smoking, firefighting, and the CYP2E1 genotype confirmed that smoking was the strongest predictor of 8-OH-dG excretion (table 4). Age, body mass index, and firefighting activity were not significant predicting factors for urinary $8-\mathrm{OH}-\mathrm{dG}$ in the multivariate analysis. The estimated median ratios suggested the possibility of a positive relation between CYP2E1 mutant type and urinary 8-OH-dG. Also, the estimated median ratios of firefighting activity were changed when the analysis was performed separately to examine the effect of GSTT1 polymorphism (table 5).

\section{Discussion}

In the present study, urinary $8-\mathrm{OH}-\mathrm{dG}$ was used to study the factors influencing oxidative DNA damage in firefighters. This study indicated that the excretion of $8-\mathrm{OH}-\mathrm{dG}$ is increased by smoking and possibly modified by the CYP2E1 and GSTT1 genotype. Although an increase in the concentration of urinary 8-OH-dG was found in very active firefighters, the increase estimated with a median ratio was not significant.

Firefighters are routinely exposed to mixtures of carcinogenic substances contained in fire smoke and building debris. Fumes and gases generated from a fire contain numerous toxic substances, including known and suspected 
carcinogens. However, whether a fire contains hazardous chemicals or how heavily individual firefighters are exposed to these chemicals is not certain. Fires vary greatly in the nature of materials burned, and the characteristics of exposures change at the scene of a fire, dependent on even short distances from it and its stage. Furthermore, the actual exposures received by firefighters depend on their job tasks at the fire and the use of respiratory protection. ${ }^{12}$ Although studies of firefighters have emphasised the importance of exposures, a definite classification of exposures to carcinogenic chemicals is nearly impossible. Time is a crucial factor in assessing exposure and possible health effects. ${ }^{13}$ We defined the exposure variable as the firefighting hours, within 5 days of the study, regardless of actual job at the scene of the fires. Five days were chosen for a cut off time because $8-\mathrm{OH}-\mathrm{dG}$ is well known as a biomarker for short term oxidative DNA damage. Thus, this study may contain misclassification and the non-significant effects of firefighting activities could be at least partially due to these misclassifications. By contrast with the negative results found in firefighting activities as a whole, the analyses on subgroups suggested the possibility of a positive relation between high exposure to firefighting and genotoxicity.

Genetic polymorphisms in enzymes involved in carcinogen metabolism have been found to influence the susceptibility to cancer. The enzyme CYP1A1 has aryl hydrocarbon hydroxylase activity, and its higher activity is shown to be associated with an increased risk of lung cancer. ${ }^{14}$ Two point mutations of the CYP1A1 gene were reported: one in the 3' non-coding region ( $M s p \mathrm{I}$ polymorphism) and the other in the exon 7 (ile-val polymorphism). ${ }^{15}{ }^{16}$ Variant allele homozygotes of each polymorphism have been shown to be correlated with an increased risk of lung cancers related to smoking. ${ }^{17} 18$ The CYP2E1 gene may be important in human carcinogenesis if it governs the metabolic activation of $\mathrm{N}$-nitrosamines and other low molecular weight carcinogens. ${ }^{19}$ It has been suggested that CYP2E1, which is highly inducible in lung tissue, actively participates in pulmonary carcinogenesis induced by cigarette smoking. ${ }^{20}$ Pst I polymorphisms in the 5'-flanking region of the human CYP2E1 gene has been shown to cause marked differences in its transcriptional activity, and the activity was greater with the $\mathrm{c} 2 / \mathrm{c} 2$ genotype than with the $\mathrm{cl} / \mathrm{cl}$ genotype. ${ }^{21} \mathrm{~A}$ study reported that homozygosity in the $\mathrm{c} 1 / \mathrm{c} 1$ genotype significantly increases the risk of developing hepatocellular carcinoma in cigarette smokers. ${ }^{22}$ However, the $\mathrm{c} 1 / \mathrm{c} 2$ and $\mathrm{c} 2 / \mathrm{c} 2$ genotypes were associated with a significantly increased risk of oral cancer. ${ }^{23}$ In this study, the CYP2E1 mutant type (c1/c2, c2/c2) showed higher concentrations of urinary $8-\mathrm{OH}-\mathrm{dG}$. We assume that the greater enzymatic activities of CYP2E1 are related to the formation of $8-\mathrm{OH}-\mathrm{dG}$ and repair of the oxidative DNA damage. The implication of this study in carcinogenesis is not clear and needs to be explored further.
The phenotypic absence of GSTM1 activity is due to homozygosity for an inherited deletion of these genes. This GSTM1 null genotype has been shown to be related to the susceptibility for cancer. ${ }^{24-27}$ Although not much is known about the association between GSTT1 and risk of cancer, the GSTT1 null genotype was reported to be associated with an increased risk of some cancers. ${ }^{28}{ }^{29}$ In our study, the GSTM1 and GSTT1 polymorphisms were not found to be significant factors that influenced urinary 8-OH-dG. However, GSTT1 polymorphism modified the influence of firefighting activity on the excretion of 8-OH-dG.

Reactive oxygen species such as superoxide, hydroxyl radical, hydrogen peroxide, and lipid peroxide are generated in the human body under normal conditions. One of the oxidative DNA products, $8-\mathrm{OH}-\mathrm{dG}$, is enhanced by $x$ ray irradiation and chemical carcinogens, ${ }^{30} 31$ but most of it is removed by the DNA repairing enzyme system or excreted in the urine. ${ }^{32} 33$ Therefore, the amount of urinary $8-\mathrm{OH}-\mathrm{dG}$ can be an useful biomarker of exposure to carcinogens. Cigarette smoke contains numerous carcinogens. It has been shown to generate reactive oxygen species and to induce oxidative damage in isolated DNAs as well as to produce $8-\mathrm{OH}-\mathrm{dG}$ in cell cultures. ${ }^{34}{ }^{35}$ It has been reported that smokers have a $50 \%$ higher concentration of urinary $8-\mathrm{OH}-\mathrm{dG}$ than non-smokers, ${ }^{11}$ which correlates with our study, which showed that smokers who smoke $>20$ cigarettes a day showed a $48 \%$ increase in the excretion of $8-\mathrm{OH}-\mathrm{dG}$.

Diet was not significantly related to the concentration of urinary 8-OH-dG. One reason for this negative result might be that the Korean diet does not include very much grilled meat. Also, age was not a significant predictor of 8-OH-dG excretion in the present firefighters, whose age ranged from 21 to 58 . However, the excretion decreased with increasing age in the regression model. A possible explanatory factor of reduced excretion in the older group is the likelihood that newer workers, being younger and less senior, would be more likely to have exposure to smoke and fumes and to engage in strenuous activity. More senior firefighters are likely to be administrators, and thus have less active involvement. ${ }^{4}$

Although the study of the effects on health according to the chemical nature of fires is of great interest, our data did not completely clarify all aspects of this problem. However, this study showed that smoking and CYP2E1 gene polymorphism may be important factors in carcinogenesis and that the GSTT1 positive genotype may be a genetic susceptibility factor in firefighters who are exposed regularly to chemical carcinogens.

\footnotetext{
1 Brandt-Rauf PW, Fallon LF Jr, Tarantini T, et al. Health hazards of fire fighters: exposure assessment. $\mathrm{Br} F$ Ind Med 1998:45:606-12.

2 Beaumont JJ, Chu GST, Jones JR, et al. An epidemiologic study of cancer and other causes of mortality in San Francisco firefighters. Am f Ind Med 1991:19:357-72.

3 Golden AL, Markowitz SB, Landrigan PJ. The risk of cancer in firefighters. Occup Med 1995:10:803-20.

cer in firefighters. Occup Med 1995:10:803-20.
4 Feuer E, Rosenman K. Mortality in police and firefighters in New Jersey. Am f Ind Med 1986:9:517-27.
} 
5 Sama SR, Martin TR, Davis L, et al. Cancer incidence among Massachusetts firefighters: 1982-6. Am f Ind Med :18:47-54

6 Aronson KJ, Tomlinson GA, Smith L. Mortality among fire fighters in metropolitan Toronto. Am F Ind Med 1994:26: 89-101.

7 Heyer N, Weiss NS, Demers P, et al. Cohort mortality study of Seattle fire fighters: 1945-1983. Am F Ind Med 1990:17: 493-504

8 Burnett CA, Halperin WE, Lalich NR, et al. Mortality among fire fighters: a 27 state survey. Am f Ind Med 1994 26:831-3.

9 Tornling G, Gustavsson P, Hogstedt C. Mortality and cancer incidence in Stockholm fire fighters. Am f Ind Med 1994:25:219-28.

10 Inoue $\mathrm{T}, \mathrm{Mu} \mathrm{Z}$, Sumikawa $\mathrm{K}$, et al. Effect of physical exercise on the content of 8-hydroxydeoxyguanosine in
nuclear DNA prepared from human lymphocytes. $\mathcal{F} p n \mathcal{F}$ Cancer Res 1993:84:720-5.

11 Loft S, Vistisen K, Ewertz M, et al. Oxidative DNA damage estimated by 8-hydroxydeoxyguanosine excretion in humans: influence of smoking, gen

12 Golden AL, Markowitz SB, Landrigan PJ. The risk of cancer in firefighters. Occup Med 1995:10:803-20.

13 Lees PSJ. Combustion products and other firefighter exposures. Occup Med 1995:10:691-706.

14 Kuori RE, McKinney CE, Slomiany DJ, et al. Positive correlation between high aryl hydrocarbon hydroxylase activity and primary lung cancer as analysed in cryopreserved lymphocytes. Cancer Res 1982:42:5030-7.

15 Kawajiri K, Nakachi K, Imai $\mathrm{K}$, et al. Identification of genetically high risk individuals to lung cancer by DNA polymorphisms of the cytochrome P4501A1 gene. FEBS Lett 1990:263:131-3.

16 Hayashi S, Watanabe J, Nakachi K, et al. Genetic linkage of lung cancer-associated MspI polymorphisms with amino acid replacement in the heme binding region of the human acid replacement in the heme binding region of the human

17 Nakachi K, Imai K, Hayashi S, et al. Genetic susceptibility to squamous cell carcinoma of the lung in relation to cigato squamous cell carcinoma of the lung in relation
rette smoking dose. Cancer Res 1991:51:5177-80.

18 Kihara M, Kihara M, Noda K. Risk of smoking for squamous and small cell carcinomas of the lung modulated by combinations of CYP1A1 and GSTM1 gene polymorphisms in a Japanese population. Carcinogenesis 1995:16 2331-6.

19 Guengerich FP, Kim DH, Iwasaki M. Role of human cytochrome P-450IIEI in the oxidation of many low molecular weight cancer suspects. Chem Res Toxicol 1991:4:168-79.

20 Villard PH, Seree E, Lacarelle B, et al. Effect of cigarette smoke on hepatic and pulmonary cytochrome P450 in mouse: evidence for CYP2E1 induction in lung. Biochem Biophys Res Commun 1994:202:1731-7.

21 Hayashi S, Watanabe J, Kawajiri K. Genetic polymorphisms in the 5'-flanking region change trascriptional regulation of the human cytochrome P450IIEI gene. F Biochem 1991: 110:559-65.
$22 \mathrm{Yu} \mathrm{M}$, Gladek-Yarborough A, Chiamprasert S, et al. Cytochrome P450 2E1 and glutathione S-transferase M1 polymorphisms and susceptibility to hepatocellular carcinoma. Gastroenterology 1995:109:1266-73.

23 Hung HC, Chuang J, Chien YC, et al. Genetic polymorphisms of CYP2E1, GSTM1, and GSTT1; environmental factors and risk of oral cancer. Cancer Epidemiol Biomarkers Prev 1997:6:901-5.

24 Katoh T, Nagata N, Kuroda Y, et al. Glutathione S-transferase M1(GSTM1) and T1(GSTT1) genetic polymorphism and susceptibility to gastric and colorectal morphism and susceptibility to gastric and col

25 Nakajima T, Elovaara E, Anttila S, et al. Expression and polymorphism of glutathione S-transferase in human ungs: risk factors in smoking-related lung cancer. Carcinogenesis 1995:16:707-11.

26 Kihara M, Kihara M, Noda K. Lung cancer risk of GSTM1 null genotype is dependent on the extent of tobacco smoke exposure. Carcinogenesis 1994:15:415-18.

27 Hirvonen A, Pelin K, Tammilehto L, et al. Inherited GSTM1 and NAT2 defects as concurrent risk modifiers in asbestos-related human malignant mesothelioma. Cancer Res 1995:55:2981-3.

28 Elexpuru-Camiruaga J, Buxton N, Kandula V, et al. Susceptibility to astrocytoma and meningioma: influence of allelism at glutathione S-transferase (GSTT1 and GSTM1) and cytochrome P-450 (CYP2D6) loci. Cancer Res 1995:55:4237-9.

29 Deakin M, Elder J, Hendrickse C, et al. Glutathione S-transferase GSTT1 genotypes and susceptibility to cancer: studies of interactions with GSTM1 in lung, oral, gastric, and colorectal cancers. Carcinogenesis 1996:17:8814.

30 Bergtold DS, Berg CD, Simic MG. Urinary biomarkers in radiation therapy of cancer. Adv Exp Med Biol 1990:264: 311-16.

31 Kasai H, Nishimura S, Kurokawa Y, et al. Oral administration of the renal carcinogen, potassium bromate, specifically produces 8-hydroxydeoxyguanosine in rat target organ DNA. Carcinogenesis 1987:8:1959-61.

32 Kasai H, Crain PF, Kuchino Y, et al. Formation of 8-hydroxyguanine moiety in cellular DNA by agents 8-hycosy cinogenesis 1986:7:1849-51.

33 Sigenaga M, Gimeno CJ, Ames BN. Urinary 8-hydroxy-2deoxyguanosine as a biological marker of in vivo oxidative DNA damage. Proc Natl Acad Sci USA 1989:86:9697-701.

34 Leanderson P, Tagesson C. Cigarette smoke-induced DNA damage: role of hydroquinone and catechol in the formation of the oxidative DNA-adduct, 8-hydroxydeoxyguanosine. Chem Biol Interact 1990:75:7181.

35 Leanderson P, Tagesson C. Cigarette smoke-induced DNA damage in cultured human lung cells: role of hydroxyl radicals and endonuclease activation. Chem Biol Interact 1992:810:197-208.

\section{Open reviewing}

Many journals, including the BMJ, have moved to a system of open reviewing, whereby authors know the names of reviewers of their papers. Research has shown that named reviews, although not of better quality than anonymous reviews, are not of worse quality either. Therefore in the interests of transparency, it seems fair to let authors know who has reviewed their paper. At Occupational and Environmental Medicine we have considered the issue carefully. There are some concerns that reviewers, especially those who are more junior, might feel intimidated and not wish to make negative comments about papers submitted by senior people in the field. On the other hand, some reviewers might hide behind the cloak of anonymity to make unfair criticisms so as to reduce the chances of publication by rivals. We have decided to introduce initially a system of open reviewing if the reviewers agree explicitly. So when a reviewer is sent a paper, he or she is asked to indicate whether we can disclose their name or not when sending the authors their comments. We will be monitoring this to see how many of our reviewers are happy to be named. If it is most of them, we will move to a system of open reviewing as the norm, with a possible "opt out" clause for reviewers. 